\title{
Retrospective Evaluation of Corrosive Substance Ingestion: Single Center Experience
}

\author{
Koroziv Madde Alımlarının Retrospektif Değerlendirilmesi: Tek Merkez Deneyimi
}

\author{
(1) Mustafa Zanyar Akkuzu, (1) Orhan Sezgin, (1) Osman Özdoğan, (1) Serkan Yaraş, (1) Enver Uçbilek, \\ (1) Fehmi Ateș, (1) Engin Altıntaş
}

Mersin University Faculty of Medicine, Department of Gastroenterology, Mersin, Turkey

\begin{abstract}
Introduction: Caustic substance ingestion is a serious problem due to high morbidity and mortality. Chemical products used in homes are the source of accidental or deliberate caustic exposures that can be seen in people of different ages. The severity of the lesions produced by the caustic substances in the tissue depends on the type, amount and concentration of the caustic agent taken, as well as the time of contact with the mucosa. In this article, we aimed to evaluate the demographic characteristics, endoscopic results, clinical findings and complications of our patients admitted to our university hospital for corrosive substance ingestion.
\end{abstract}

Methods: We retrospectively identified adult patients admitted to our hospital between 2013-2019 for corrosive substance ingestion. We examined the endoscopy findings and endoscopy requirement within 24 hours of ingestion in 75 adult patients with acute corrosive substance ingestion.

Results: Forty-three patients (57\%) were female and 32 (43\%) were male. The mean age of the males was $39.3 \pm 14.50$ years and the mean age of the females was $34.1 \pm 16.91$ years. Sixteen corrosive substance ingestions (21.3\%) were suicidal and 59 (78.6\%) were accidental. Thirty-seven patients (49.3\%) were asymptomatic and did not require endoscopy and seven patients (9.3\%) were recommended endoscopy but they did not consent. Fifteen patients (20\%) had normal endoscopic findings, nine (12\%) had Los Angeles (LA) grade A esophagitis, five (6.6\%) patients had LA Grade B esophagitis, and one patient (1.3\%) had LA grade D esophagitis due to crystal drain opener ingestion. One patient (1.3\%) with history of thinner ingestion had esophageal polyp and Schatzki ring. Regarding corrosive substances, 25 patients (33.3\%) had bleach ingestion. There was no mortality due to corrosive substance ingestion.

Conclusion: Caustic substance ingestion is often inadvertent and is accompanied by mild symptoms or esophageal damage. Endoscopy may not be performed, especially in asymptomatic people with bleach or softener ingestion. In suicidal ingestions,

\section{öZ}

Amaç: Kostik madde içilmesi yüksek morbidite ve mortalite nedeniyle ciddi bir sorun teșkil etmektedir. Evlerde kullanılan kimyasal ürünler, farklı yaşlardaki kişilerde görülebilen kaza veya kasıtlı olarak kostik maruz kalmaların kaynağıdır. Kostik maddelerin dokuda ürettiği lezyonların ciddiyeti, alınan kostik maddenin türüne, miktarına ve konsantrasyonuna, ayrıca mukoza ile temas zamanına bağlıdır. Bu çalışmada, üniversite hastanemize koroziv madde içilmesi nedeniyle bașvuran hastalarımızın demografik özelliklerini, endoskopik sonuçlarını, klinik bulgularını ve komplikasyonlarını değerlendirmeyi amaçladık.

Yöntemler: Hastanemize koroziv madde alımı nedeniyle 20132019 yılları arasında başvuran yetișkin hastaları geriye dönük olarak hastane veri kayıt sisteminden tespit ettik. Akut korozif madde alımlı 75 erişkin hastanın, alımdan sonraki 24 saat içinde endoskopi gereksinimi ve endoskopi yapılmış olanların endoskopi bulgularını inceledik.

Bulgular: Hastaların 43'ü (\%57) kadın, 32'si (\%43) erkekti. Erkeklerin yaş ortalaması $39,3 \pm 14,50$, kadınların yaş ortalaması ise $34,1 \pm 16,91$ yıl idi. On altısında $(\% 21,3)$ koroziv madde alımı intihar amaçlı olup, 59'unda $(\% 78,6)$ yanlışlıkla alım şeklindeydi. Otuz yedi $(\% 49,3)$ hasta asemptomatik olup endoskopi gerektirmedi, $7(\% 9,3)$ hastaya endoskopi önerilmesine rağmen hastalar endoskopiyi kabul etmedi. On beş (\%20) hastada endoskopi normal, 9 (\%12) hastada özofajit Los Angeles (LA) grade A, $5(\% 6,6)$ hastada özofajit LA grade B, 1 $(\% 1,3)$ hasta kristal lavabo açıcısı içmiş olup özofajit LA grade D mevcuttu. Bir $(\% 1,3)$ hasta da tiner içmiş olup özofageal polip, Schatzki halkası șeklinde raporlanmıștı. Alınan maddelere baktığımızda $25(\% 33,3)$ hastada çamașır suyu içimi mevcuttu. Koroziv madde içimine bağlı mortalite yoktu.

Sonuç: Kostik madde içimleri sıklıkla yanlışlıkla olup, hafif semptomlar veya özofageal hasar ile geçmektedir. Özellikle çamaşır suyu veya yumuşatıcı içen asemptomatik kişilerde endoskopi yapılmayabilir. Intihar amaçlı alımlarda hastalar 
serious injuries may occur because patients ingest too much, and endoscopy is indicated for suicidal ingestion. Endoscopy should be used only to evaluate esophageal and gastric injury and to determine prognosis. A careful psychiatric evaluation should be performed for suicidal ingestion.

Keywords: Caustic intoxication, corrosive substance ingestion, esophagitis çok fazla içtikleri için ciddi yaralanmalar olabilmektedir ve bu durumlarda endoskopi işlemi endikedir. Endoskopi sadece özofagus ve mide yaralanmasını değerlendirmek ve prognoz tayini için kullanılmalıdır. İntihar amaçlı alımlarda dikkatli bir psikiyatrik değerlendirme yapılmalıdır.

Anahtar Kelimeler: Kostik intoksikasyonu, koroziv madde alımı, özofajit

\section{Introduction}

Caustic substance ingestion is a serious problem due to high morbidity and mortality. Chemical cleaning products used in households are the most common cause of caustic exposure. Accidental or intentional caustic exposure may occur at different ages (1). Diluted acids or alkalis generally cause limited mucosal damage. In contrast, concentrated caustic agents with $\mathrm{pH}<2$ or $>12$ can cause severe esophageal damage as well as a wide range of gastrointestinal injuries (2-5). Most patients with mild injuries recover without serious consequences. However, numerous corrosive intoxications can cause serious chemical injuries and death $(4,6,7)$. It may cause complications such as pneumonia, respiratory failure, bleeding, perforation, stenosis and fistula $(8,9)$. Mortality is most commonly caused by tracheal necrosis and perforation of the esophagus or stomach, followed by mediastinitis or peritonitis $(6,10,11)$. The severity of the lesions caused by the caustic substances depends on the type, amount and concentration of the caustic agent taken, as well as the duration of contact with the mucosa.

In this article, we aimed to evaluate the demographic characteristics, endoscopic results, clinical findings and complications of patients admitted to our university hospital with corrosive substance ingestion.

\section{Methods}

We retrospectively identified adult patients admitted to the Mersin University Faculty of Medicine Hospital between 2013-2019 for corrosive substance ingestion. We retrospectively reviewed the medical reports of patients with acute corrosive ingestion who were evaluated endoscopically within 24 hours after ingestion and who did not require endoscopy. We classified these patients according to gender and age, type of corrosive substance detected and endoscopy results. Ethics committee approval was obtained from Mersin University Faculty of Medicine Clinical Research Ethics Committee (decision no: 104, date: 06/03/2019). Informed consent was obtained from the patients during the endoscopy and the study was completed by retrospective file scanning.

\section{Statistical Analysis}

SPSS 21.0 for Windows program was used to calculate the statistical analysis. Descriptive statistical methods were used to evaluate the study data.

\section{Results}

A total of 75 adults were admitted to our hospital with acute corrosive substance ingestion. Forty-three patients (57\%) were female and 32 (43\%) were male. The mean age of the men was $39.3 \pm 14.50$ years and the mean age of the women was $34.1 \pm 16.91$ years. In 16 (21.3\%) of our patients, corrosive substance ingestion was suicidal and it was accidental in 59 (78.6\%). Regarding gender distribution in suicidal ingestion, seven patients (43.7\%) were male and 9 (56.2\%) were female.

There was a small amount of accidental ingestion in 37 patients (49.3\%) and the patients were also asymptomatic, so endoscopy was not required. Seven patients (9.3\%) with mild symptoms were recommended endoscopy but they did not consent. Fifteen patients (20\%) had normal endoscopic findinsgs. Nine (12\%) had Los Angeles (LA) grade A esophagitis, five (6.6\%) patients had LA grade B esophagitis, and one patient (1.3\%) had LA grade D esophagitis due to crystal drain opener ingestion. One patient (1.3\%) with history of thinner ingestion had esophageal polyp and Schatzki ring.

Regarding ingested corrosive substance, twenty-five patients (33.3\%) had a history of bleach ingestion and only four patients (16\%) had LA grade A esophagitis, while the others were either asymptomatic or had normal endoscopic findings. The corrosive substance could not be reached in 24 patients (32\%) and only reported as corrosive substances, and two (8.3\%) had LA grade A esophagitis, the others were either asymptomatic or had normal endoscopic findings. We think that those who had anamnesis as "corrosive substance ingestion" also ingested bleach. Details of other corrosive exposures are presented in Table 1. According to the anamnesis, the amount in suicidal ingestions was higher than the amounts in accidental ingestions.

None of the patients had organ perforation, organ failure or mortality.

\section{Discussion}

Oral ingestion of corrosive substances may cause perforation, necrosis and death in the acute phase. In the long term, it may cause stenosis in the esophagus and development of carcinoma. Despite various educational and legal efforts to reduce the occurrence of caustic injury, it remains a major medical problem worldwide. The most serious intoxications are mostly related to ingestion of a large amount of caustic product and suicide attempts where damage is usually extensive (911). In our series, the most common cause of ingestion was accidental (78.66\%), unlike suicidal (21.33\%). This indicates that more caution signs should be added on caustic substances.

When the studies involving caustic poisoning cases in our country are reviewed, we see that most of the cases are suicidal and include female patients (12-16). In a study of 108 cases in the Aegean region, Karaoğlu et al. (17) reported that $56.4 \%$ of the esophagitis cases due to oral ingestion of corrosive substances were women and $43.6 \%$ were male patients. In the same study, it was determined that oral ingestion of corrosive 
Table 1. Corrosive substances ingested and endoscopic findings

\begin{tabular}{|l|l|}
\hline Corrosive substance ingested & Number (\%) \\
\hline Bleach & $25(33.3 \%)$ \\
\hline Corrosive (Unknown) & $24(32 \%)$ \\
\hline Descaling agent & $8(10.6 \%)$ \\
\hline Hydrochloric acid & $6(8 \%)$ \\
\hline Thinner & $4(5.3 \%)$ \\
\hline Softener & $2(2.6 \%)$ \\
\hline Dishwashing liquid & $1(1.3 \%)$ \\
\hline Air conditioner cleaner & $1(1.3 \%)$ \\
\hline Peroxide & $1(1.3 \%)$ \\
\hline Agrochemicals & $1(1.3 \%)$ \\
\hline Tincture of iodine & $1(1.3 \%)$ \\
\hline Crystal drain opener & $1(1.3 \%)$ \\
\hline LA: Los Angeles & \\
\hline
\end{tabular}

Table 2. Alkali caustic substances

\begin{tabular}{|l|l|}
\hline Caustic substance & Chemical content \\
\hline Drain Openers & Sodium hydroxide, sodium hypochlorite \\
\hline Oven cleaners & Sodium hydroxide \\
\hline Toilet cleaners & Ammonium chloride \\
\hline Household cleaners & $\begin{array}{l}\text { Ammonium hydroxide, ammonium } \\
\text { chloride }\end{array}$ \\
\hline Bleaching products & Sodium hypochlorite, hydrogen peroxide \\
\hline Dishwashing liquid & Sodium carbonate, sodium silicate \\
\hline Watch battery & Sodium hydroxide, potassium hydroxide \\
\hline Hair straighteners & Calcium hydroxide, lithium hydroxide \\
\hline
\end{tabular}

\section{Table 3. Acidic caustic substances}

\begin{tabular}{|l|l|}
\hline Caustic substance & Chemical content \\
\hline Toilet cleaners & Hydrochloric acid, sulfuric acid, phosphoric acid \\
\hline Metal cleaners & Hydrochloric acid \\
\hline Pool cleaners & Hydrochloric acid \\
\hline Rust inhibitors & Hydrochloric acid, sulfuric acid, hydrofluoric acid \\
\hline Battery fluids & Sulfuric acid \\
\hline
\end{tabular}

substance for suicidal purposes was $16.3 \%$ in men and $39 \%$ in women. Fifty-seven percent of our patients were female and $43 \%$ were male. The mean age of men was 39.3 years and the mean age of women was 34.1 years. Regarding gender distribution in suicidal ingestion, $56.2 \%$ were women.

Mortality after caustic ingestion is high worldwide and ranges from $5 \%$ to $20 \%(2,4,7,8)$. In our study, the mortality rate was $0 \%$. Only one of our patients had widespread ulcerated lesions in the esophageal mucosa and stomach as a result of drinking a crystal drain opener, and no complication occurred during the follow-up. In one patient, intubation was required due to laryngeal edema developed after hydrochloric acid ingestion, the patient refused endoscopy after extubation and escaped
Endoscopic findings

LA grade A esophagitis in four (16\%), no problem in others.

LA grade A esophagitis in two (8.33\%), no problem in others.

Three (37.5\%) had normal endoscopic findings, two (25\%) had LA grade A esophagitis, wo (25\%) were asymptomatic, one (12.5\%) did not give approval.

wo (33.33\%) had LA grade B esophagitis, two (33.33\%) had LA grade A esophagitis, two $33.33 \%$ ) did not accepte endoscopy and one of them was intubated-extubated, then the patient escaped from the hospital.

There was no problem in three (75\%), esophageal polyp and Schatzki ring in one (25\%).

Asymptomatic, endoscopy was not needed.

Asymptomatic, endoscopy was not needed.

Normal endoscopic findings.

LA grade B Esophagitis.

Asymptomatic, endoscopy was not needed.

Asymptomatic, endoscopy was not needed.

Ulcers covering the entire mucosa, LA grade D Esophagitis. from the hospital for psychiatric reasons. Our other patients had no serious problems.

Alkaline agents (Table 2) are swallowed without stimulating protective reflexes because they are tasteless and odorless (18). Solids are more difficult to swallow because of their adhesion to mucous membranes (18). Generally, alkaline substances damage the esophagus rather than the stomach, while acid substances (Table 3) can cause severe stomach damage (18). The most important difference between alkali and acid injury is the rapid penetration of alkalis into tissues (18). Especially swallowing bleach ( $5 \%$ sodium hypochlorite) has been reported frequently, but rarely causes serious esophageal injury. In our series, there was a 33\% incidence of bleach ingestion, and only four (16\%) of the patients who ingested bleach had LA grade A esophagitis, the others were either asymptomatic or had normal endoscopic findings. In $32 \%$ of the patients, substance information was not available and reported as corrosive only, and only $8 \%$ had LA grade A esophagitis. Therefore, we think that endoscopic evaluation is not necessary especially in asymptomatic patients with bleach ingestion. Our patient with the most damage had grade $\mathrm{D}$ esophagitis with drain opener ingestion.

Depending on the nature of the substance, diagnostic endoscopy can be performed in symptomatic patients. Kikendall (19) and Poley et al. (20) stated that it was better to perform endoscopy between 48-72 hours because the damage would be better detected. There are some literatures stated that endoscopy should not be performed after the first 24 hours to avoid iatrogenic rupture (21). In many case series, this time limitation has been found to be safer for complications. It is recommended that endoscopy is performed regardless of the presence of oropharyngeal burns in severely affected pediatric and adult patients with symptoms such as stridor or marked oropharyngeal burn, vomiting, drooling, rejection of eating during accidental ingestion (2124). Endoscopy is still controversial in patients with a suspected history of ingestion. Some authors advocate endoscopy only in symptomatic patients (25). In our cases, 44 (58.6\%) patients were asymptomatic and 
did not require endoscopy or did not consent. When we examined the endoscopies performed after approximately one day; endoscopic examinations of 15 patients (20\%) were normal and nine patients (12\%) had grade A, five patients (6.6\%) had grade B, and one patient (1.3\%) had grade D esophagitis. One patient (1.3\%) had esophageal polyp and Schatzki ring. Therefore, we recommend endoscopy according to the nature of the substance and the ingestion of large amounts of corrosive substances only in symptomatic patients.

Currently, there are some unconfirmed treatment approaches in the prevention and treatment of complications. These include caustic neutralization, corticosteroids, collagen synthesis inhibitors, antibiotics, heparin, early esophageal dilatation and stent placement in the esophagus. Urgent surgery is only effective in the early intervention in cases with perforation. In our patients, there was only one patient who was hospitalized and no patient had perforation. He improved during follow-ups.

Although there is no uniform guidance for nutritional support for patients after caustic injury, and the approach varies from patient to patient, appropriate nutritional support reduces the risk of malnutrition or infection. This may be particularly important in elderly patients $(26,27)$. In our patient with grade D esophagitis, we provided IV nutrition support and oral intake was started during the follow-up. Nutritional support and hydration are very important for the healing of esophageal mucosa.

\section{Conclusion}

It was observed that ingestion of caustic material was often accidental, and generally improved with mild course. Depending on the type and amount of corrosive substance, endoscopy may not be performed especially in asymptomatic people who drink bleach or softeners. In suicidal ingestion, serious injuries may occur because patients drink too much, so endoscopy is indicated in patients with suicidal ingestion. Endoscopic evaluation is required in patients with resistant symptoms. Endoscopy should be used only to evaluate esophageal and gastric injury and to determine prognosis. We think that a careful psychiatric evaluation should be performed in suicidal ingestions.

Ethics Committee Approval: Ethics committee approval was obtained from Mersin University Faculty of Medicine Clinical Research Ethics Committee (decision no: 104, date: 06/03/2019).

Informed Consent: Informed consent was obtained from the patients during the endoscopy and the study was completed by retrospective file scanning.

Peer-review: Externally peer-reviewed.

Author Contributions: Concept - M.Z.A., O.S.; Data Collection and/or Processing - M.Z.A.; Analysis and/or Interpretation - S.Y., O.S., M.Z.A.; Literature Search - O.S., F.A.; Writing Manuscript - M.Z.A.; Critical Review - M.Z.A, O.S., E.U., F.A., S.Y., O.Ö.

Conflict of Interest: The authors have no conflict of interest to declare. Financial Disclosure: The authors declared that this study has received no financial support.

\section{References}

1. Mrazova K, Navratil T, Pelclova D. Consequences of ingestions of potentially corrosive cleaning products, one-year follow-up. Int J Electrochem Sci 2012; 7: $1734-48$.

2. Cheng HT, Cheng CL, Lin CH, Tang JH, Chu YY, Liu NJ, et al. Caustic ingestion in adults: The role of endoscopic classification in predicting outcome. BMC Gastroenterol 2008; 8: 31-7.

3. Contini S, Scarpignato C. Caustic injury of the upper gastrointestinal tract: A comprehensive review. World J Gastroenterol 2013; 19: 3918-30.

4. Lu LS, Tai WC, Hu ML, Wu KL, Chiu YC. Predicting the progress of caustic injury to complicated gastric outlet obstruction and esophageal stricture using modified endoscopic mucosal injury grading scale. Biomed Res Int 2014.

5. Koschny R, Herceg M, Stremmel W, Eisenbach C. Fatal course of a suicidal intoxication with hydrochloric acid. Case Rep Gastroenterol 2013; 7: 89-96.

6. Chibishev A, Simonovska N, Bozinovska C, Pereska Z, Smokovski I, Glasnovic M. Respiratory complication from acute corrosive poisonings in adults. Mater Sociomed 2014; 26: 80-3.

7. Kluger Y, Ishay OB, Sartelli M, Katz A, Ansaloni L, Gomez CA, et al. Caustic ingestion management: World society of emergency surgery preliminary survey of expert opinion. World J Emerg Surg 2015; 10: 48.

8. Caganova B, Foltanova T, Plackova S, Placha K, Bibza J, Puchon E, et al. Caustic effects of chemicals: Risk factors for complications and mortality in acute poisoning. Monatsh Chem 2017; 148: 497-503.

9. Cabral C, Chirica M, de Chaisemartin C, Gornet JM, Munoz-Bongrand N, Halimi B, et al. Caustic injuries of the upper digestive tract: A population observational study. Surg Endosc 2012; 26: 214-21.

10. Ceylan H, Ozokutan BH, Gündüz F, Gözen A. Gastric perforation after corrosive ingestion. Pediatr Surg Int 2011; 27: 649-53.

11. Plackova S, Placha K, Caganova B, Bibza J. A retrospective analysis of caustic ingestions in Slovakia Clin Toxicol 2013; 51: 313-4.

12. Yeșil O, Akoğlu H, Onur Ö, Güneysel Ö. Acil servise bașvuran zehirlenme olgularının geriye dönük analizi. Marmara Medical Journal 2008; 21: 26-32.

13. Gökben Çetin N, Beydilli H, Tomruk Ö. Acil servise başvuran intoksikasyon olgularının geriye dönük analizi. S.D.Ü. Tıp Fak Derg 2004; 11: 7-9.

14. Kavalcı C, Durukan P, Çevik Y, Özer M, İkizceli İ. Zehirlenme olgularının analizi: Yeni bir hastanenin bir yıllık deneyimi. Türkiye Acil Tıp Dergisi. 2006; 6: 163-6.

15. Ok G, Erbüyün K, Mirzai T et al. Acil servise bașvuran zehirlenme olgularının retrospektif olarak incelenmesi. Toksikoloji Dergisi 2006; 4: 5-9.

16. Al B, Güllü M, Küçüköner M, et al. Dicle Üniversitesi Tıp Fakültesi Acil Servisine ilaçlara bağlı zehirlenmeler ile başvuran hastaların epidemiyolojik özellikleri. Toksikoloji Dergisi. 2006; 4: 11-20.

17. Karaoğlu A. Önder, Özütemiz Ö. Akut koroziv özofajit: 108 olgunun değerlendirilmesi. Turk J Gastroenterol 1996; 7: 1-4.

18. Naharcı i, Tüzün A. Kostik özofagus yaralanmaları, güncel gastroenteroloji Aralık 2005 S:226-233, http://guncel.tgv.org.tr/journal/3/pdf/8.pdf

19. Kikendall JW. Caustic ingestion injuries. Gastroenterol Clin North Am 1991; 20: 847-57.

20. Poley JW, Steyerberg EW, Kuipers EJ, Dees J, Hartmans R, Tilanus HW, et al. Ingestion of acid and alkaline agents: outcome and prognostic value of early upper endoscopy. Gastrointest Endosc 2004; 60: 372-7. 
21. Lamireau T, Rebouissoux L, Delphine D, Lancelin F, Vergnes P, Fayon M. Accidental caustic ingestion in children: Is endoscopy always mandatory? J Pediatr Gastroenterol Nutr 2001; 33: 81-4.

22. Gupta SK, Croffie JM, Fitzgerald JF. Is esophagogastroduodenoscopy necessary in all caustic ingestions?. J Pediatr Gastroenterol Nutr. 2001; 32: 50-3.

23. Celik B, Nadir A, Sahin E, Kaptanoglu M. Is esophagoscopy necessary for corrosive ingestion in adults? Dis Esophagus 2009; 22: 638-41.

24. Christesen HB. Prediction of complications following unintentional caustic ingestion in children. Is endoscopy always necessary? Acta Paediatr 1995; 84: 1177-82.
25. Millar AJW, Numanoğlu A, Coran AG. Editors. Pediatric Surgery. 1st Ed. Philadelphia, Elsevier. 2012; 919-926.

26. Rondanelli M, Peroni G, Miccono A, Guerriero F, Guido D, Perna S. Nutritional management in an elderly man with esophageal and gastric necrosis after caustic soda intake: a case report. Ther Clin Risk Yönetimi 2016; 12: 129-33.

27. Chirica M, Munoz-Bongrand N, Sarfati E, Cattan P. Emergency management in caustic injuries. In: Di Saverio S, Catena F, Ansaloni L, Coccolini F, Velmahos G, editors. Acute Care Surgery Manual. 1st edition Volume 1. Springer International Publishing; Cham, Switzerland: 2017, p. 471-483. 